\title{
Channels for water efflux and influx involved in volume regulation of murine spermatozoa
}

\author{
C Callies, T G Cooper and C H Yeung \\ Centre of Reproductive Medicine and Andrology of the University, Domagkstrasse 11, D-48129 Münster, Germany \\ Correspondence should be addressed to T G Cooper; Email: trevorg.cooper@ukmuenster.de \\ C Callies is now at the Institute of Physiology II of the University, Münster, Germany
}

\begin{abstract}
The nature of the membrane channels mediating water transport in murine spermatozoa adjusting to anisotonic conditions was investigated. The volume of spermatozoa subjected to physiologically relevant hypotonic conditions either simultaneously, or after isotonic pre-incubation, with putative water transport inhibitors was monitored. Experiments in which quinine prevented osmolyte efflux, and thus regulatory volume decrease (RVD), revealed whether water influx or efflux was being inhibited. There was no evidence that sodium-dependent solute transporters or facilitative glucose transporters were involved in water transport during RVD of murine spermatozoa since phloretin, cytochalasin B and phloridzin had no effect on volume regulation. However, there was evidence that $\mathrm{Hg}^{2+}$ - and $\mathrm{Ag}^{+}$-sensitive channels were involved in water transport and the possibility that they include aquaporin 8 is discussed. Toxic effects of these heavy metals were ruled out by evidence that mitochondrial poisons had no such effect on volume regulation.

Reproduction (2008) 136 401-410
\end{abstract}

\section{Introduction}

The difference in osmolality between luminal fluids in the epididymis, seminal vesicles and female tract imposes an osmotic challenge on spermatozoa upon ejaculation (Cooper \& Barfield 2006). For the mouse, spermatozoa have to regulate their volume before fertilisation occurs (Yeung et al. 2006) or infertility ensues (Yeung et al. 2000). The channels through which osmolytes are shed from murine spermatozoa to drive water efflux in response to cell swelling have been identified as $\mathrm{K}^{+}$channels (Barfield et al. 2005), $\mathrm{Cl}^{-}$ channels (Yeung et al. 2005) and $\mathrm{K}^{+}-\mathrm{Cl}^{-}$co-transporters (Klein et al. 2006), but the route of water is as yet unknown. Knowledge of this may be useful to provide new diagnostic tests of sperm function, suggest new therapies for infertility, improve cryopreservation protocols or design male contraceptives mimicking natural infertility stemming from inadequate volume regulation (Cooper \& Barfield 2006).

Water cannot pass through occupied $\mathrm{K}^{+}$channels, as the water of hydration is stripped off the ions before they enter the selectivity filter (Armstrong 2003, Saparov \& Pohl 2004) and as the water can only diffuse slowly across the lipid bilayers, its transport across plasma membranes occurs mainly through aquaporins (AQPs) at 10- to 100-fold higher rates (see Agre et al. 2002). Among mammalian cells, 13 members of the AQP family have so far been identified; each being dominantly present in different tissues with most individual cell types having more than one isoform (see Castle 2005, Verkman 2005). Isoforms of AQPs used by spermatozoa for water transport have not been identified, although the presence of some proteins has been reported (Table 1).

In studies of osmolyte channels, inhibitors specific for certain channels have been proved useful in their pharmacological identification (Cooper \& Yeung 2007); however, there are no specific inhibitors for AQP and $\mathrm{HgCl}_{2}$ is the most established classical inhibitor used (see Yang et al. 2006). The mechanism of action and inhibitory site are known to be the binding of $\mathrm{Hg}^{2+}$ to the cysteine residue (cys-187 in AQP1, as in most other AQPs) near to one of the two Asn-Pro-Ala (NPA) motifs that form the water pore of different AQP isoforms (Preston et al. 1993, see also Agre 2006).

Besides AQPs, there are other membrane proteins that participate in osmotic water transport; although they are present at lower densities than AQPs, their biological importance relative to AQPs has not been studied in most tissues (Verkman \& Mitra 2000, see Table 1). Inhibitors of facilitative glucose transport, cytochalasin B and phloretin, decrease reversibly the osmotic water transport across the plasma membranes of several cell types (Table 1), but they are not entirely specific in their action. Nevertheless, the observation that phloretin inhibits water transport in ovine and human spermatozoa (Curry et al. 1995) and 
Table 1 Putative channels involved in water transport and their presence in spermatozoa.

\begin{tabular}{|c|c|c|}
\hline \multicolumn{3}{|c|}{ Channels and transporters involved in water transport } \\
\hline $\mathrm{AQP}$ & Aquaporins & Meinild et al. (1998), Verkman \& Mitra (2000) and Verkman (2005) \\
\hline SLC5A1 & Sodium-glucose co-transporter & Loo et al. (2002) \\
\hline GLUT (SLC2As) & Glucose transporters & Fischbarg et al. $(1989,1990)$ \\
\hline \multirow[t]{2}{*}{ SLC14A1 } & Urea transporter & Yang \& Verkman (2002) \\
\hline & Anion channels & Pohl (2004) \\
\hline \multirow[t]{2}{*}{ CFTR } & Cystic fibrosis transmembrane & \\
\hline & Conductance regulator & Hasegawa et al. (1992) \\
\hline VRAC & Volume-regulated anion channels & Nilius (2004) \\
\hline \multicolumn{3}{|l|}{ Inhibitors of water channels } \\
\hline \multirow[t]{7}{*}{$\mathrm{Hg}$} & AQP1 & Preston et al. (1993) and Niemietz \& Tyerman (2002) \\
\hline & AQP2, AQP5, AQP6 & Agre \& Kozono (2003) \\
\hline & $\mathrm{AQP3}$ & Kuwahara et al. (1997) \\
\hline & AQP8 & Nielsen et al. (2007) \\
\hline & AQP9 & Castle (2005) \\
\hline & Not MIP, AQP4, AQP7 & Ishibashi et al. (1997) and Agre et al. (2002) \\
\hline & AQP11?** & Gorelick et al. (2006), Ishibashi (2006) and Yakata et al. (2007) \\
\hline \multirow[t]{2}{*}{$\mathrm{Ag}$} & AQP1 & Niemietz \& Tyerman (2002) \\
\hline & AQP8 & Bienert et al. (2007) \\
\hline TEA & AQP1 & Brooks et al. (2000), Agre \& Kozono (2003) and Detmers et al. (2006) \\
\hline Phloretin & AQP9 & Tsukaguchi et al. $(1998,1999)$ \\
\hline Cytochalasin B, phloretin & Glucose transporters & Fischbarg et al. $(1989,1990)$ \\
\hline \multirow[t]{2}{*}{ Cytochalasin B, phloretin } & SLC2A1, SLC2A2, SLC2A3, SLC2A4 & $\begin{array}{l}\text { Haber et al. (1993), Maher et al. (1996), Kasahara \& Kasahara (1997), } \\
\text { Angulo et al. (1998), Martin et al. (2003) and Walker et al. (2005) }\end{array}$ \\
\hline & Not SLC2A5 & $\begin{array}{l}\text { Burant et al. (1992), Burant \& Davidson (1994) and Helliwell et al. } \\
\text { (2000) }\end{array}$ \\
\hline Cytochalasin B & SLC2A8, SLC2A9 & Doege et al. (2000), Augustin et al. (2004) and Gomez et al. (2006) \\
\hline Phloridzin & SLC5A1 & $\begin{array}{l}\text { Loo et al. (1996, 1999, 2002), Yang \& Verkman }(1998,2002) \text { and } \\
\text { Zeuthen et al. (2001) }\end{array}$ \\
\hline \multicolumn{3}{|c|}{ Presence of putative water channel proteins in spermatozoa } \\
\hline SLC5A10 not SLC5A1 & Dog & Rigau et al. (2002) \\
\hline AQP7 & Rat, man & Calamita et al. (2001) and Saito et al. (2004) \\
\hline AQP8 & Rat & Calamita et al. (2001) \\
\hline Not AQP1 & Ram, human & Curry et al. (1995) and Liu et al. (1995) \\
\hline SLC2A3, SLC2A8, SLC2A9 & Mouse & $\begin{array}{l}\text { Urner \& Sakkas (1999), Schurmann et al. (2002), Gomez et al. (2006) } \\
\text { and Kim \& Moley (2007) }\end{array}$ \\
\hline SLC2A3, SLC2A5 & Pig, man & Burant et al. (1992) and Sancho et al. (2007) \\
\hline
\end{tabular}

${ }^{*} ?$, suspected but not proven.

phloridzin, an inhibitor of sodium-coupled solute transporters, may block water influx into murine spermatozoa (Barfield et al. 2005) suggests that the approach of using transport inhibitors may throw light on the water channels employed by spermatozoa during regulatory volume decrease (RVD).

In the present work, the types of water channels involved in physiological sperm volume regulation were probed using various inhibitors of water transport. The volume of viable spermatozoa, ascertained from their forward scatter of a laser beam, was measured by a flow cytometer, since this permits the simultaneous determintation of cell vitality. Transfer to a hypotonic medium within the physiological range should trigger osmotic water influx and a related increase in cell volume which will induce RVD. Quinine, an effective inhibitor of sperm RVD, causes unopposed influx of water into the cell by blocking the $\mathrm{K}^{+}$efflux responsible for driving water outwards for RVD. This swelling will be hampered if water transport is prohibited by co- or pre-incubation with putative water transport inhibitors. Therefore, failure of quinine to swell the treated sperm will provide clear evidence of inhibition of water influx.

\section{Results}

\section{Long time-course protocol}

\section{Control and quinine-treated spermatozoa}

When murine spermatozoa were released into hypotonic medium, and first measured at $5 \mathrm{~min}$, the cell volume gradually increased to reach a steady state by $30 \mathrm{~min}$. In the presence of quinine, the cells were far larger than controls at the first time point studied, but volume slightly decreased between 15 and $30 \mathrm{~min}$ (Fig. 1). The large difference in the extent of response of the controls among mice (compare Figs 1 and 2) was unanticipated and may reflect the osmotic load of spermatozoa from different mice. As a consequence, all results from each experiment were expressed as a ratio of the control values.

\section{Phloridzin-treated cells}

None of the concentrations of phloridzin tested influenced the vitality of the spermatozoa, as indicated by the exclusion of the DNA stain propidium iodide ( $\mathrm{Pl}$; Table 2). Two-way ANOVA revealed that there were no 


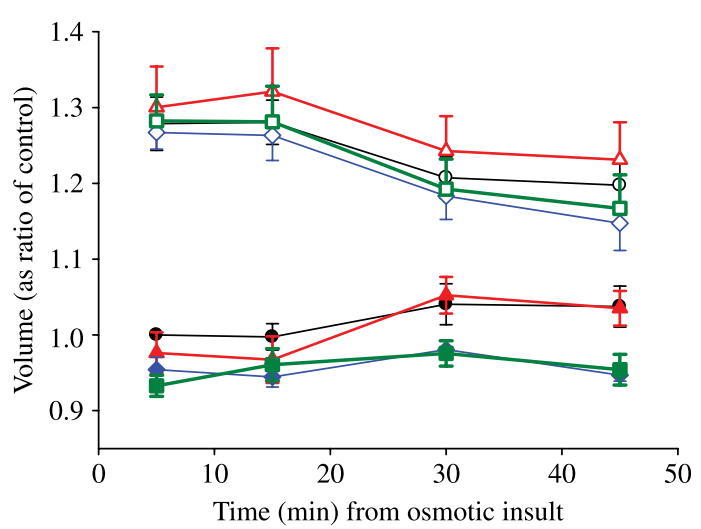

Figure 1 The effect of phloridzin on volume regulation under long time-course conditions. The relative volume of murine epididymal spermatozoa (mean \pm s.E.M.; ordinate) with time after osmotic challenge (abscissa) when transferred to hypotonic $(330 \mathrm{mmol} / \mathrm{kg}$ ) medium alone (filled black circles, control), hypotonic medium containing $800 \mu \mathrm{mol} / \mathrm{l}$ quinine alone (open black circles), phloridzin alone at $100 \mu \mathrm{mol} / \mathrm{l}$ (filled red triangles), $500 \mu \mathrm{mol} / \mathrm{l}$ (filled blue diamonds) or $1000 \mu \mathrm{mol} / /$ (filled green squares) or with $800 \mu \mathrm{mol} / \mathrm{l}$ quinine together with phloridzin at $100 \mu \mathrm{mol} / \mathrm{l}$ (open red triangles), $500 \mu \mathrm{mol} / \mathrm{l}$ (open blue diamonds) or $1000 \mu \mathrm{mol} / \mathrm{l}$ (open green squares). At least 5000 spermatozoa were registered at each time point from each of seven epididymides. Spermatozoa from the same mice were used for all treatments.

statistically significant differences in cell volume between control cells and those treated with phloridzin at any concentration, or between cells treated with quinine alone or with quinine together with phloridzin

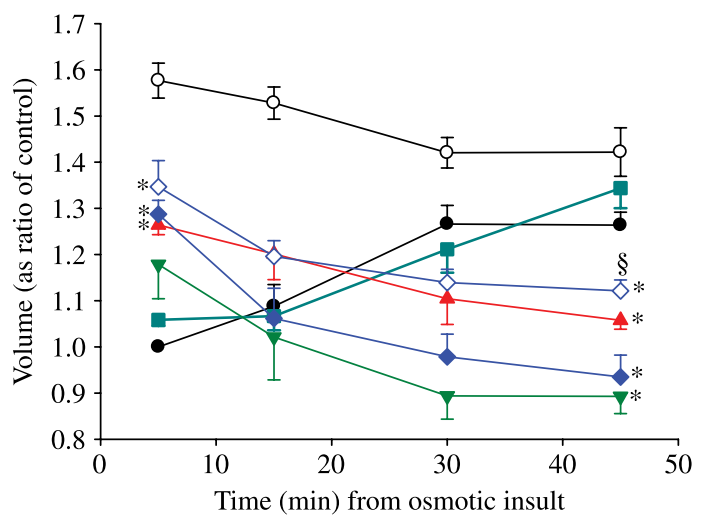

Figure 2 The effect of mercury on volume regulation under long time-course conditions. The relative volume of murine epididymal spermatozoa (mean \pm s.E.M.; ordinate) with time after osmotic challenge (abscissa) when transferred to hypotonic $(330 \mathrm{mmol} / \mathrm{kg}$ ) medium alone (filled black circles, control), hypotonic medium containing $800 \mu \mathrm{mol} / \mathrm{l}$ quinine alone (open black circles), $\mathrm{Hg}^{2+}$ alone at $10 \mu \mathrm{mol} / \mathrm{l}$ (filled cyan squares), $30 \mu \mathrm{mol} / \mathrm{l}$ (filled red up triangles), $100 \mu \mathrm{mol} / \mathrm{l}$ (filled blue diamonds) or $300 \mu \mathrm{mol} / \mathrm{l}$ (filled green down triangles) or with $800 \mu \mathrm{mol} / \mathrm{l}$ quinine together with $100 \mu \mathrm{mol} / / \mathrm{Hg}^{2+}$ (open blue diamonds). Statistical differences: *, between test and control at the same time point; $\S$, between test and quinine treated at the same time point; $P<0.05$. At least 5000 spermatozoa were registered at each time point from each of eight epididymides. Spermatozoa from the same mice were used for all treatments.
(Fig. 1). As phloridzin had no effect in the long time-course experiments, it was not studied in the short time-course protocol.

\section{Mercury-treated cells}

None of the concentrations of $\mathrm{Hg}^{2+}$ tested reduced the viability of spermatozoa (Table 2). As a trend in volume was observed, with Hg-treated cells shrinking as control cells increased in volume, one-way ANOVA was applied at the 5 - and 45-min time points. At 5 min, cells incubated with 30 and $100 \mu \mathrm{mol} / / \mathrm{Hg}^{2+}$ and $100 \mu \mathrm{mol} / \mathrm{l} \mathrm{Hg}$ with quinine were significantly larger than the controls. By $45 \mathrm{~min}$ all concentrations of $\mathrm{Hg}^{2+}$, except $10 \mu \mathrm{mol} / \mathrm{l}$, reduced cell volume to below that of the control cells. Cells pre-incubated in $\mathrm{Hg}^{2+}$ and quinine were significantly smaller than cells in quinine alone (Fig. 2).

\section{Initial time-course protocol}

\section{Control and quinine-treated spermatozoa}

When murine epididymal spermatozoa were first preincubated for $10 \mathrm{~min}$ in isotonic medium $(430 \mathrm{mmol} / \mathrm{kg}$ ) and then transferred to hypotonic medium, the cells maintained their volume, first measured at $20 \mathrm{~s}$, for the entire 5 min with a slight increase in size during the last $3 \mathrm{~min}$. In the presence of quinine, cells were far larger than controls at the first time point and maintained this volume over the 5 min studied (Figs 3-5).

\section{Mercury-treated cells}

At the concentration tested $(100 \mu \mathrm{mol} / \mathrm{l}), \mathrm{Hg}^{2+}$ had no effect on cell viability (Table 2). Spermatozoa preincubated with $\mathrm{Hg}^{2+}$ for $10 \mathrm{~min}$ before hypotonic challenge retained their small size during the time when control cells were slightly increasing in size. At $20 \mathrm{~s}$, there were no differences between the volumes of $\mathrm{Hg}^{2+}$-treated spermatotoa and the controls, but $\mathrm{Hg}^{2+}$ prevented the increase in size normally produced by quinine. By $305 \mathrm{~s}$, the mercury-treated cells were significantly smaller than the controls (which had increased in size). Thus, the slight cell swelling under control conditions, reflecting the inefficiency of RVD, was abolished by $\mathrm{Hg}^{2+}$ (Fig. 3).

\section{Silver-treated cells}

At the concentration tested $(30 \mu \mathrm{mol} / \mathrm{l}), \mathrm{Ag}^{+}$had no effect on cell viability (Table 2). At $20 \mathrm{~s}$, cells treated with silver and quinine were significantly smaller than those incubated in quinine alone and this was maintained during incubation until $305 \mathrm{~s}$ (Fig. 4). Spermatozoa incubated with $\mathrm{Ag}^{+}$before hypotonic challenge swelled to volumes between those of the control and quininetreated spermatozoa; but the variability was such that they were not significantly different from either group (Fig. 4). 
Table 2 Viability of murine spermatozoa during incubation with channel inhibitors.

\begin{tabular}{|c|c|c|c|c|}
\hline \multirow{3}{*}{$\begin{array}{l}\text { Treatment } \\
\text { Long time-course }\end{array}$} & \multicolumn{4}{|c|}{$\%$ viable cells (mean \pm s.E.M.) } \\
\hline & \multicolumn{4}{|c|}{ Min } \\
\hline & 5 & 15 & 30 & 45 \\
\hline Control & $77.1 \pm 3.3$ & $70.2 \pm 2.7$ & $67.5 \pm 3.8$ & $64.6 \pm 2.9$ \\
\hline $\begin{array}{l}\text { Quinine } \\
\qquad(800 \mu \mathrm{mol} / \mathrm{l})\end{array}$ & $77.4 \pm 2.6$ & $73.2 \pm 2.6$ & $62.1 \pm 3.7$ & $69.0 \pm 6.2$ \\
\hline $\begin{array}{l}\text { Phloridzin } \\
\qquad(100 \mu \mathrm{mol} / \mathrm{l})\end{array}$ & $72.7 \pm 3.3$ & $65.9 \pm 3.3$ & $60.0 \pm 4.6$ & $60.0 \pm 2.2$ \\
\hline $\begin{array}{l}\text { Phloridzin } \\
\qquad(500 \mu \mathrm{mol} / \mathrm{l})\end{array}$ & $74.9 \pm 3.7$ & $67.5 \pm 2.8$ & $63.3 \pm 2.9$ & $62.0 \pm 2.5$ \\
\hline $\begin{array}{l}\text { Phloridzin } \\
\qquad(1000 \mu \mathrm{mol} / \mathrm{l})\end{array}$ & $78.1 \pm 3.0$ & $68.6 \pm 2.1$ & $63.6 \pm 2.0$ & $37.7 \pm 2.3$ \\
\hline $\begin{array}{l}\text { Phloridzin } \\
\qquad(100 \mu \mathrm{mol} / \mathrm{l})+\text { qui- } \\
\text { nine }(800 \mu \mathrm{mol} / \mathrm{l})\end{array}$ & $77.6 \pm 3.9$ & $69.5 \pm 3.7$ & $67.1 \pm 3.1$ & $68.8 \pm 5.3$ \\
\hline $\begin{array}{l}\text { Phloridzin } \\
\qquad(500 \mu \mathrm{mol} / \mathrm{l})+\text { qui- } \\
\text { nine }(800 \mu \mathrm{mol} / \mathrm{l})\end{array}$ & $76.5 \pm 2.0$ & $71.2 \pm 2.4$ & $65.5 \pm 5.0$ & $60.1 \pm 4.3$ \\
\hline $\begin{array}{l}\text { Phloridzin } \\
\qquad(1000 \mu \mathrm{mol} / \mathrm{l})+\text { qui- } \\
\text { nine }(800 \mu \mathrm{mol} / \mathrm{l})\end{array}$ & $89.1 \pm 1.1$ & $76.1 \pm 2.4$ & $65.2 \pm 4.3$ & $71.8 \pm 4.3$ \\
\hline Control & $78.1 \pm 3.0$ & $76.5 \pm 1.1$ & $73.5 \pm 3.1$ & $69.5 \pm 3.8$ \\
\hline $\begin{array}{l}\text { Quinine } \\
\qquad(800 \mu \mathrm{mol} / \mathrm{l})\end{array}$ & $80.1 \pm 4.6$ & $75.4 \pm 5.1$ & $70.0 \pm 5.8$ & $74.6 \pm 1.4$ \\
\hline $\mathrm{HgCl}_{2}(10 \mu \mathrm{mol} / \mathrm{l})$ & $75.8 \pm 4.0$ & $67.1 \pm 5.0$ & $65.9 \pm 5.8$ & $68.5 \pm 8.1$ \\
\hline $\mathrm{HgCl}_{2}(30 \mu \mathrm{mol} / \mathrm{l})$ & $88.4 \pm 2.5^{\mathrm{a}}$ & $77.0 \pm 3.3$ & $77.8 \pm 2.6$ & $76.7 \pm 3.5$ \\
\hline $\mathrm{HgCl}_{2}(100 \mu \mathrm{mol} / \mathrm{l})$ & $84.6 \pm 1.2$ & $78.5 \pm 1.6$ & $74.4 \pm 2.1$ & $73.5 \pm 0.9$ \\
\hline $\mathrm{HgCl}_{2}(300 \mu \mathrm{mol} / \mathrm{l})$ & $86.2 \pm 2.2$ & $82.0 \pm 1.7$ & $78.5 \pm 2.6$ & $76.4 \pm 2.6$ \\
\hline $\begin{array}{l}\mathrm{HgCl}_{2} \\
\quad(100 \mu \mathrm{mol} / \mathrm{l})+\text { qui- } \\
\quad \text { nine }(800 \mu \mathrm{mol} / \mathrm{l})\end{array}$ & $79.0 \pm 2.1$ & $76.0 \pm 2.4$ & $74.3 \pm 3.1$ & $72.0 \pm 1.7$ \\
\hline
\end{tabular}

\begin{tabular}{ll}
\hline Initial time-course & Min $(0-5)$ \\
\hline Control & $62.3 \pm 3.2$ \\
Quinine $(800 \mu \mathrm{mol} / \mathrm{l})$ & $68.9 \pm 2.3$ \\
$\mathrm{HgCl}_{2}(100 \mu \mathrm{mol} / /)$ & $67.7 \pm 3.1$ \\
$\mathrm{HgCl}_{2}(100 \mu \mathrm{mol} / \mathrm{l})+$ quinine $(800 \mu \mathrm{mol} / \mathrm{l})$ & $76.4 \pm 0.9$ \\
$\mathrm{AgNO}_{3}(30 \mu \mathrm{mol} / \mathrm{l})$ & $66.1 \pm 2.1$ \\
$\mathrm{AgNO}_{3}(30 \mu \mathrm{mol} / \mathrm{l})+$ quinine $(800 \mu \mathrm{mol} / \mathrm{l})$ & $74.1 \pm 1.9$ \\
Phloretin $(800 \mu \mathrm{mol} / /)$ & $79.3 \pm 3.6$ \\
Phloretin $(800 \mu \mathrm{mol} / \mathrm{l})+$ quinine $(800 \mu \mathrm{mol} / \mathrm{l})$ & $85.6 \pm 0.9^{\mathrm{a}}$ \\
Control & $68.2 \pm 3.8$ \\
Quinine & $74.4 \pm 2.4$ \\
Phloretin $(800 \mu \mathrm{mol} / \mathrm{l})+$ furosemide $(1000 \mu \mathrm{mol} / \mathrm{l})$ & $89.0 \pm 0.9^{\mathrm{a}}$ \\
Phloretin $(800 \mu \mathrm{mol} / \mathrm{l})+\mathrm{TEA}(5 \mathrm{mM})$ & $88.9 \pm 0.6^{\mathrm{a}}$ \\
Phloretin $(800 \mu \mathrm{mol} / \mathrm{l})+$ quinine $(800 \mu \mathrm{mol} / \mathrm{l})+$ & $87.9 \pm 1.3^{\mathrm{a}}$ \\
furosemide $(1000 \mu \mathrm{mol} / /)$ & \\
Phloretin $(800 \mu \mathrm{mol} / \mathrm{l})+$ quinine $(800 \mu \mathrm{mol} / \mathrm{l})+$ & $87.1 \pm 1.4^{\mathrm{a}}$ \\
$\quad$ TEA $(5 \mathrm{mM})$ & \\
Control & $72.3 \pm 1.5$ \\
Quinine & $71.3 \pm 1.5$ \\
Cytochalasin B $(5 \mu \mathrm{mol} / /)$ & $74.2 \pm 3.4$ \\
Cytochalasin B $(20 \mu \mathrm{mol} / \mathrm{l})$ & $77.0 \pm 1.7$ \\
Cytochalasin B $(40 \mu \mathrm{mol} / \mathrm{l})$ & $75.6 \pm 2.4$ \\
Cytochalasin B $(5 \mu \mathrm{mol} / \mathrm{l})+$ quinine $(800 \mu \mathrm{mol} / /)$ & $77.9 \pm 0.4$ \\
Cytochalasin B $(20 \mu \mathrm{mol} / \mathrm{l})+$ quinine $(800 \mu \mathrm{mol} / \mathrm{l})$ & $73.5 \pm 1.3$ \\
\hline
\end{tabular}

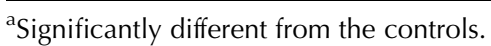

\section{Phloretin-treated cells}

The viability of phloretin- and quinine-treated spermatozoa was not depressed below that of the controls (Table 2). At the first (20 s) time point, cells treated with phloretin and transferred to quinine were as large as

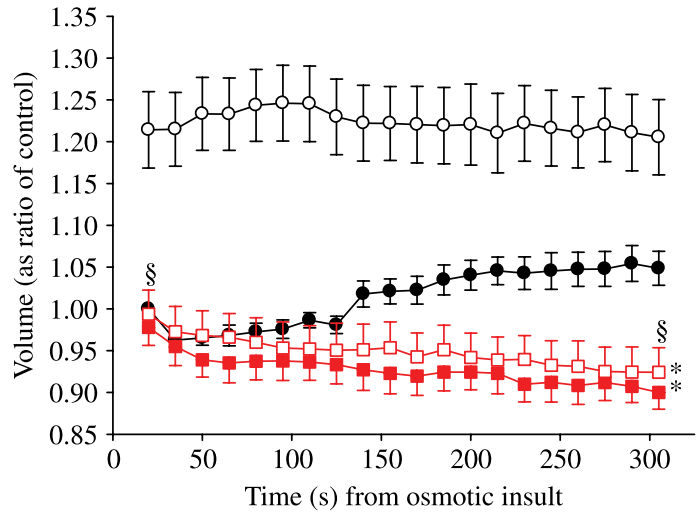

Figure 3 The effect of mercury on volume regulation under initial time-course conditions. The relative volume of murine epididymal spermatozoa (mean \pm S.E.M.; ordinate) with time after osmotic challenge (abscissa) with pre-incubation in isotonic $(430 \mathrm{mmol} / \mathrm{kg}$ ) medium alone (circles) for $10 \mathrm{~min}$ and then transfer to hypotonic $(330 \mathrm{mmol} / \mathrm{kg}$ ) medium alone (filled black circles, control) or hypotonic medium containing $800 \mu \mathrm{mol} / \mathrm{l}$ quinine alone (open black circles), or preincubation in isotonic medium containing $100 \mu \mathrm{mol} / \mathrm{l} \mathrm{Hg}^{2+}$ (squares) and transfer to hypotonic medium containing $100 \mu \mathrm{mol} / \mathrm{I} \mathrm{Hg}^{2+}$ (filled red squares) or $800 \mu \mathrm{mol} / /$ quinine together with $100 \mu \mathrm{mol} / / \mathrm{l} \mathrm{Hg}^{2+}$ (open red squares). Statistical differences: ${ }^{*}$, between test and control at the same time point; $\S$, between test and only quinine treated at the same time point; $P<0.05$. Between 20000 and 60000 spermatozoa were registered over the entire period from each of seven epididymides. Spermatozoa from the same mice were used for all treatments.

untreated cells in quinine alone, but their size diminished during incubation so that by $305 \mathrm{~s}$ they were significantly smaller than both those incubated in quinine alone and the controls. Cells incubated in phloretin alone were smaller than the controls (Fig. 5).

\section{Cytochalasin B-treated cells}

Another glucose transporter inhibitor, cytochalasin B, at 5, 20, $40 \mu \mathrm{mol} / \mathrm{l}$, with or without $800 \mu \mathrm{mol} / \mathrm{l}$ quinine, had no effect on sperm viability (Table 2). Unlike the other facilitative glucose transporter inhibitor phloretin, none of the concentrations tested had an influence on sperm volume or their response to quinine (data not shown).

\section{Phloretin + tetraethylammonium (TEA)- or phloretin+ furosemide-treated cells}

In attempts to determine the cause of the volume decline in the presence of phloretin and quinine, additional inhibitors were provided with phloretin in the pre- and post-incubation media; the voltage-gated K-channel inhibitor TEA and the potassium-chloride co-transporter (KCC, SLC12A) inhibitor furosemide. Murine spermatozoa incubated with TEA or furosemide, either alone or each with quinine, were significantly more viable than the control cells (Table 2). In the absence of phloretin, neither compound alone altered swelling in the presence of quinine (data not shown). 


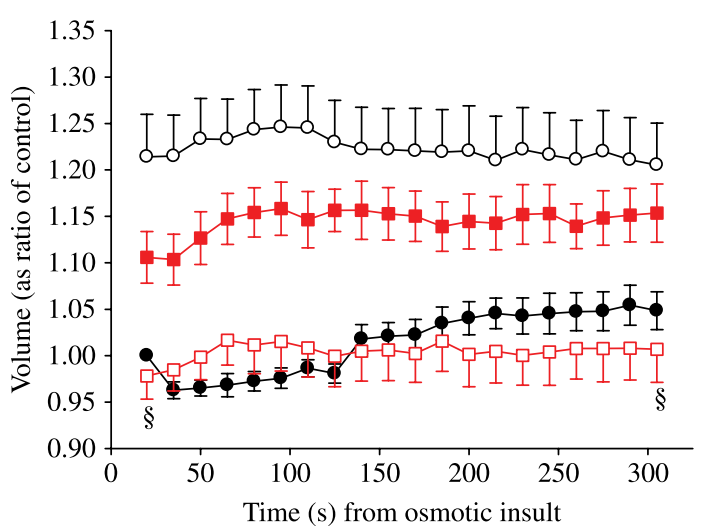

Figure 4 The effect of silver on volume regulation under initial time-course conditions. The relative volume of murine epididymal spermatozoa (mean \pm s.E.M.; ordinate) with time after osmotic challenge (abscissa) with pre-incubation in isotonic $(430 \mathrm{mmol} / \mathrm{kg}$ ) medium alone (circles) for $10 \mathrm{~min}$ and then transfer to hypotonic $(330 \mathrm{mmol} / \mathrm{kg}$ ) medium alone (filled black circles, control) or hypotonic medium containing $800 \mu \mathrm{mol} / /$ quinine alone (open black circles), or preincubation in isotonic medium containing $30 \mu \mathrm{mol} / \mathrm{I} \mathrm{Ag}^{+}$(squares) and transfer to hypotonic medium containing $30 \mu \mathrm{mol} / \mathrm{I} \mathrm{Ag}^{+}$(filled red squares) or $800 \mu \mathrm{mol} / /$ quinine together with $30 \mu \mathrm{mol} / / \mathrm{Ag}^{+}$(open red squares). Statistical differences: $\S$, between test and only quinine treated at the same time point; $P<0.05$. Between 20000 and 60000 spermatozoa were registered over the entire period from each of eight epididymides. Spermatozoa from the same mice were used for all treatments.

In half of the animals used, and in both epididymides of the same mice, both TEA and furosemide separately were partially able to delay the decline in volume occurring in the presence of quinine after pre-incubation in phloretin (responders; Fig. 6), whereas in another four mice (non-responders), the decline in volume in the phloretin- and quinine-treated spermatozoa still occurred in the presence of furosemide or TEA (Fig. 6). At the first (20 s) time point, there were no differences between volumes of cells incubated with any treatment; none was different from the phloretin plus quinine control. By 305 s, significant differences were observed between the responders and non-responders to either furosemide or TEA in the cells given phloretin with quinine.

\section{Possible toxic effects of heavy metal inhibitors}

Two mitochondrial poisons, sodium azide and rotenone, at concentrations known to be block oxidative phosphorylation and motility of spermatozoa (Van Dop et al. 1977, Aitken et al. 1997), were incubated with spermatozoa before hypo-osmotic challenge. Comparison of sperm volumes at 20 and $305 \mathrm{~s}$ demonstrated that there were no significant differences in cell volume between the controls and those in azide or rotenone or between cells incubated in azide or rotenone with quinine and those incubated in quinine alone (Fig. 7).

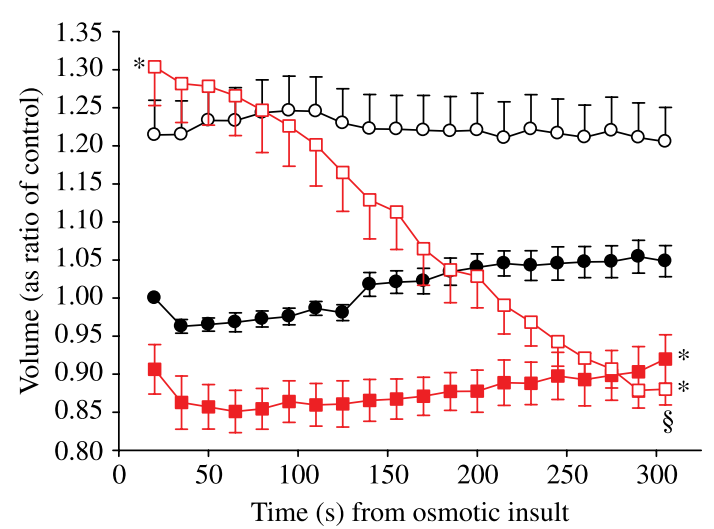

Figure 5 The effect of phloretin on volume regulation under initial time-course conditions. The relative volume of murine epididymal spermatozoa (mean \pm s.E.M.; ordinate) with time after osmotic challenge (abscissa) with pre-incubation in isotonic $(430 \mathrm{mmol} / \mathrm{kg}$ ) medium alone (circles) for $10 \mathrm{~min}$ and then transfer to hypotonic $(330 \mathrm{mmol} / \mathrm{kg}$ ) medium alone (filled black circles, control) or hypotonic medium containing $800 \mu \mathrm{mol} / \mathrm{l}$ quinine alone (open black circles), or incubation in isotonic medium containing $800 \mu \mathrm{mol} / \mathrm{l}$ phloretin (squares) and transfer to hypotonic medium containing $800 \mu \mathrm{mol} / \mathrm{l}$ phloretin alone (filled red squares) or $800 \mu \mathrm{mol} / \mathrm{l}$ quinine together with $800 \mu \mathrm{mol} / \mathrm{l}$ phloretin (open red squares). Statistical differences:

*, between test and control at the same time point; $\S$, between test and quinine treated at the same time point; $P<0.05$. Between 20 and 60000 spermatozoa were registered over the entire period from each of seven epididymides. Spermatozoa from the same mice were used for all treatments.

\section{Discussion}

Under the conditions in the long time-course protocol, osmotic water entrance into spermatozoa should be opposed by osmolyte efflux by RVD mechanisms, which in turn should be inhibited by the K-channel blocker quinine. This is demonstrated by the quinine-induced swelling as water enters the cells unopposed. Simultaneous addition of phloridzin, an inhibitor of water/solute transport, did not affect cell volume while acting alone; nor did it affect the quinine-induced swelling, suggesting that sodium-dependent glucose transporters are not involved in water transport during RVD.

Under similar conditions, however, the effects of $\mathrm{Hg}^{2+}$ were difficult to interpret. Cells were initially larger than controls, but this was followed by a decrease in volume. These results are compatible with the concept that when RVD becomes activated by the hypo-osmotic challenge, which should be immediate as in the controls, $\mathrm{Hg}^{2+}$ first inhibits water efflux more than influx, perhaps related to the time it takes to penetrate the cell and to bind to and inhibit the sulphydryl groups of the channels. Cell swelling caused by the initial inhibitory activity may trigger other, Hg-insensitive, water transport mechanisms to allow water efflux driven by osmolyte efflux in RVD. These may include $\mathrm{Cl}^{-}$/anion channels that also allow water passage (Hasegawa et al. 1992, Pohl 2004). With this protocol, in the transfer from 


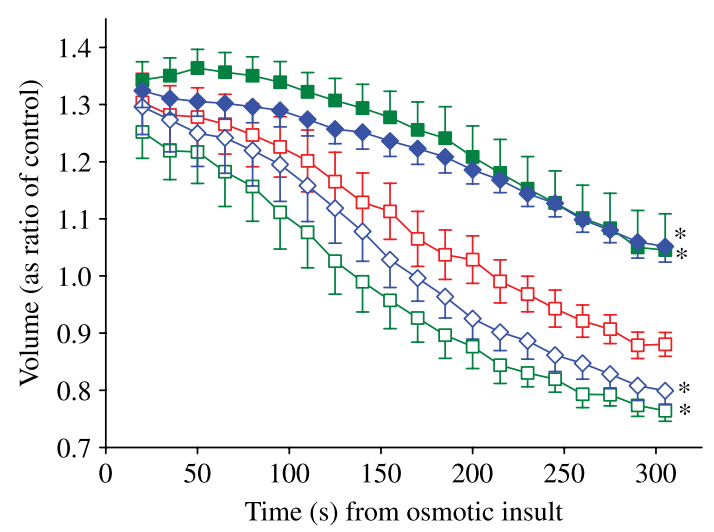

Figure 6 The effect of TEA, furosemide and phloretin on volume regulation under initial time-course conditions. The relative volume of murine epididymal spermatozoa (mean \pm s.E.M.; ordinate) with time after osmotic challenge (abscissa) after incubation in isotonic $(430 \mathrm{mmol} / \mathrm{kg}$ ) medium containing $800 \mu \mathrm{mol} / \mathrm{l}$ phloretin for $10 \mathrm{~min}$ and then transfer to hypotonic $(330 \mathrm{mmol} / \mathrm{kg}$ ) medium containing $800 \mu \mathrm{mol} / \mathrm{l}$ phloretin and $800 \mu \mathrm{mol} / /$ quinine (open red squares), $800 \mu \mathrm{mol} / /$ phloretin and $800 \mu \mathrm{mol} / /$ quinine with $5 \mathrm{mM}$ TEA (green squares), or $800 \mu \mathrm{mol} / / \mathrm{l}$ phloretin and $800 \mu \mathrm{mol} / /$ quinine with $1 \mathrm{mM}$ furosemide (blue diamonds). Spermatozoa from four of the eight animals responded to the additional inhibitors, TEA or furosemide in delaying volume decline (closed symbols), whereas four did not (open symbols). Statistical differences: *, between additional TEA or furosemide and no TEA or furosemide control at the same time point; $P<0.05$. Between 20000 and 60000 spermatozoa were registered over the entire period from each of 8 (TEA or furosemide) or 16 (no TEA; furosemide control) epididymides. Spermatozoa from the same mice were used for all treatments.

epididymal fluid (high osmolality, high $\mathrm{K}^{+}$) to the test medium, spermatozoa are subjected to both osmotic and ionic changes. Changes in membrane potential would activate ion pumps, as it occurs during copulation.

To eliminate the problematical interpretation related to an anticipated delay in the action of $\mathrm{Hg}$, the metal ion was allowed to interact with the functional groups on the transport proteins before hypo-osmotic challenge. In this experimental design (termed the initial time-course protocol), spermatozoa were pre-incubated in a medium with the mean osmolality of epididymal fluid, i.e. close to isotonic conditions (Cooper et al. 2008), so that osmotic challenges would be minimised during preincubation with the putative inhibitors without quinine. Thereafter, they were subjected to a physiological osmotic challenge in the drug in the absence or presence of quinine. In this protocol, sperm membrane repolarisation would occur under isotonic conditions, so that the subsequent transfer to the test medium would largely reflect an osmotic response.

If the pre-incubation were long enough for the water channel inhibitor to become effective, any immediate effects on water entry into the cell would become apparent; therefore, the cell volume was monitored at the earliest time-point (20 s) and continuously for $5 \mathrm{~min}$. Furthermore, as quinine blocks osmolyte efflux during RVD, resulting in cell swelling by unopposed entry of

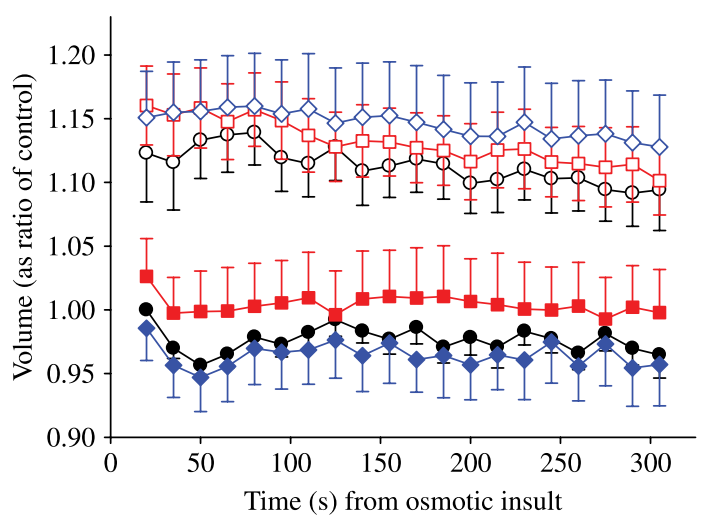

Figure 7 The effect of metabolic poisons on volume regulation under initial time-course conditions. The relative volume of murine epididymal spermatozoa (mean \pm s.E.M.; ordinate) with time after osmotic challenge (abscissa) with pre-incubation in isotonic (430 mmol $/ \mathrm{kg}$ ) medium alone (circles) for $10 \mathrm{~min}$ and then transfer to hypotonic $(330 \mathrm{mmol} / \mathrm{kg}$ ) medium alone (filled black circles, control) or hypotonic medium containing $800 \mu \mathrm{mol} / \mathrm{l}$ quinine alone (open black circles), pre-incubation in isotonic medium containing $20 \mu \mathrm{mol} / \mathrm{l}$ rotenone (squares) and transfer to hypotonic medium containing $20 \mu \mathrm{mol} / /$ rotenone alone (filled red squares) or $800 \mu \mathrm{mol} / \mathrm{l}$ quinine together with $20 \mu \mathrm{mol} / \mathrm{l}$ rotenone (open red squares), or incubation in isotonic medium containing $20 \mu \mathrm{mol} / /$ sodium azide (diamonds) and transfer to hypotonic medium containing $20 \mu \mathrm{mol} / \mathrm{l}$ sodium azide alone (filled blue diamonds) or $800 \mu \mathrm{mol} / /$ quinine together with $20 \mu \mathrm{mol} / \mathrm{l}$ sodium azide (open blue diamonds). Between 20000 and 60000 spermatozoa were registered over the entire period from each of eight epididymides. Spermatozoa from the same mice were used for all treatments.

water, any blockade of water entry would be demonstrated by cell volumes similar to those of the controls even in the presence of quinine.

Indeed, after pre-incubation, $\mathrm{Hg}^{2+}$ was able to block the volume increase that normally occurs under hypotonic conditions when RVD is inhibited by quinine, which suggests that $\mathrm{Hg}^{2+}$ blocks water entry. Because both AQP8 and AQP7 proteins are present in rat spermatozoa (Calamita et al. 2001) and $\mathrm{Hg}^{2+}$ inhibits AQP8 (Nielsen et al. 2007), but not AQP7 (Ishibashi et al. 1997), AQP8 may be mediating the water influx into murine spermatozoa. In the presence of quinine, blockade of water influx was also blocked by $\mathrm{Ag}^{+}$since the volume of the treated cells was no different from that of control cells. Since AQP8 is $\mathrm{Ag}^{+}$sensitive (Biernert et al. 2007), this is further evidence that AQP8 may be involved in water influx in spermatozoa. However, in the absence of quinine, $\mathrm{Ag}^{+}$alone allowed water influx to some extent, since cell volumes were intermediate between those of the controls and those with quinine. The water channel involved here is not known.

The ability of murine spermatozoa to transport water during volume regulation in the presence of sodium azide and rotenone, at concentrations known to prevent sperm motility and mitochondrial activity (Aitken et al. 1997), suggests that the effects of $\mathrm{Hg}^{2+}$ and $\mathrm{Ag}^{+}$on water transport were not due to any general toxic actions but 
more specific effects on water transport, most likely the binding of $\mathrm{Hg}^{2+}$ to the cysteine residue (cys-187) near to one of the two Asn-Pro-Ala (NPA) motifs that form the water pore of different AQP isoforms (Preston et al. 1993, see also Agre 2006).

Evidence for the involvement of glucose transporters in water transport includes the ability of specific inhibitors of glucose transport, cytochalasin B and phloretin to decrease reversibly the osmotic water transport across the plasma membranes of several cell types (Fischbarg et al. 1989, 1990). Previous studies have suggested that they may be involved in spermatozoa since water transport in ovine and human spermatozoa are sensitive to phloretin (Curry et al. 1995). Although glucose transporters have been detected in spermatozoa (Table 1), in this study neither phloretin nor cytochalasin $B$ prevented water influx in the presence of quinine, making the glucose transporter an unlikely candidate as a water channel in murine spermatozoa.

In the presence of quinine and phloretin, cell volume was the same as that of cells incubated in quinine alone, indicating that water influx had not been inhibited by phloretin. Furthermore, neither was water efflux inhibited, since with time the spermatozoa shrank to volumes smaller than the controls. This suggests that phloretin promotes osmolyte efflux through channels insensitive to quinine. In the absence of quinine, phloretin reduced sperm volume below the level of the control cells. This implies that under the control experimental conditions, RVD was not efficient enough to prevent hypo-osmotic swelling completely and phloretin either inhibited water entry or was promoting water efflux. It is unlikely that these effects are due to abnormal metabolism through phloretin's inhibition of glucose transport via the glucose transporter, since the BWW medium contains the respiratory substrates lactate and pyuvuate. Although phloretin can inhibit AQP9 (Castle 2005), where antibodies have been used on epididymal sections, there are no reports of this AQP in luminal spermatozoa (Ruz et al. 2006, Da Silva et al. 2007).

Experiments designed to determine the possible alternative RVD mechanism in the presence of quinine and phloretin, leading to the observed water efflux, showed that both TEA and furosemide were able, in the same animals, to delay the onset of RVD. Unlike quinine, TEA itself has no effect on RVD of murine spermatozoa (Barfield et al. 2005), indicating that quinine-sensitive and TEAinsensitive voltage-sensitive $\mathrm{K}^{+}$channels are preferentially utilised for $\mathrm{K}^{+}$efflux in initial RVD. However, in the presence of quinine and phoretin in swollen cells, TEAsensitive channels were clearly activated after a short delay. TEA blocks voltage-sensitive $\mathrm{K}^{+}$channels, small conductance, $\mathrm{Ca}^{2+}$-sensitive $\mathrm{K}^{+}$channels $\left(\mathrm{SK}_{\mathrm{Ca}}\right.$ : Coetzee et al. 1999) and large conductance $\mathrm{K}^{+}$channels $\left(\mathrm{BK}_{\mathrm{Ca}}\right.$ : Rosenfeld et al. 2001), so it may be blocking $\mathrm{K}^{+}$channels operating in swollen, but not normal, cells. Furosemide alone is capable of blocking RVD of murine spermatozoa with a delayed time course under long time-course conditions (Klein et al. 2006) and the $\mathrm{K}-\mathrm{Cl}$ co-transporter it blocks in the present study is presumably operating earlier in swollen cells in the presence of quinine and phloretin in the responder animals.

That spermatozoa from only four of eight mice responded in this way reflects the between-male variability in osmotic responses. These responses may depend, among other things, on the ability of the spermatozoa to take up osmolytes, the ability of the epididymis to provide them, the osmolalities experienced within that epididymis, the length of time stored within the epididymis, which depends on sexual activity and nocturnal seminal emissions, and the expression of the osmolyte and water channels.

In summary, there is no evidence that sodiumdependent glucose transporters, glucose transporters or AQP9 are involved in water transport during RVD of murine spermatozoa; but the $\mathrm{Hg}^{2+}$ - and $\mathrm{Ag}^{+}$-sensitive AQP8 is a likely candidate as water channel.

\section{Materials and Methods}

\section{Animal experiments}

All experiments were done on adult male mice of the C57BL/6N strain (Charles River, Sulzfeld, Germany) and were conducted according to the German Federal Law on the Care and Use of Laboratory Animals (licence G67/2001). Spermatozoa were obtained from the cauda epididymidis as described previously (Barfield et al. 2005) and were subjected to two experimental protocols. In the first (long time-course) procedure, spermatozoa were subjected to a hypotonic insult of physiological proportions at the same time as the inhibitors, as described previously (Barfield et al. 2005). Briefly, segments of the caudal tubule were excised and their contents transferred to BWW medium containing $4 \mathrm{mg} \mathrm{BSA} / \mathrm{ml}$ (Biggers et al. 1971) with osmolality raised with $\mathrm{NaCl}$ to $330 \mathrm{mmol} / \mathrm{kg}$ similar to that of female tract fluids (Yeung et al. 2000; $\mathrm{BWW}_{330}$ ) and incubated for up to $45 \mathrm{~min}$ at $37^{\circ} \mathrm{C}$. Water channel inhibitors with or without quinine $(800 \mu \mathrm{mol} / \mathrm{l})$ were present from the outset. At 10-15 min intervals, aliquots were diluted with the same incubation medium containing $6 \mu \mathrm{g} / \mathrm{ml} \mathrm{Pl}$, gently mixed and drawn into the flow cytometer. The transfer from epididymal fluid to the lower osmolality, lower $\mathrm{K}^{+}$experimental medium will also repolarise the membranes of the spermatozoa that are essentially in $\mathrm{K}^{+}$-rich epididymal fluid. This will activate the ion pumps maintaining membrane potential in the same way as it occurs naturally upon ejaculation. However, ion loss during RVD is passive.

In the second protocol (initial time-course), the tubule contents were transferred to an albumin $(4 \mathrm{mg} / \mathrm{ml})$-containing BWW medium with osmolality raised with $\mathrm{NaCl}$ to $430 \mathrm{mmol} / \mathrm{kg}\left(\mathrm{BWW}_{430}\right.$; similar to that of epididymal fluid (Yeung et al. 1999) and close to isotonic with cauda epididymidal spermatozoa (Cooper et al. 2008)) for preincubation at $37^{\circ} \mathrm{C}$ in the presence of water transport inhibitors but not quinine. After $10 \mathrm{~min}$, the sample was transferred to BWW $_{330}$ containing $6 \mu \mathrm{g} / \mathrm{ml} \mathrm{Pl}$ as well as the inhibitor with or 
without $800 \mu \mathrm{mol} / \mathrm{l}$ quinine and read immediately and continuously for $5 \mathrm{~min}$ in the flow cytometer. In this procedure, changes in membrane potential would occur in the 10-min preincubation period under isotonic conditions, but the subsequent challenge would be purely osmotic.

For each protocol, spermatozoa from the same mice were used for all conditions in a given replicate of an experiment.

\section{Flow cytometry}

The flow cytometer was a FACS 500 (Beckmann-Coulter Epics, Krefeld, Germany) using $488 \mathrm{~nm}$ laser as excitation source, a $19{ }^{\circ} \mathrm{C}$ for forward scatter detection and red PI fluorescence detection for gating of live cells. The machine alignment was checked on the day of use with fluorescent spheres (Fluorospheres, Beckmann-Coulter) in order to ensure that voltages and signals were reproducible between studies. For the long timecourse protocol, samples were read from $5 \mathrm{~min}$ and then every 10 or $15 \mathrm{~min}$ for $45 \mathrm{~min}$. For the initial time-course protocol, samples were read as soon as possible after sperm dispersion and 20 s after injection into the equipment (the time taken for the sample to load automatically and fill the dead space of sample tubing) in continuous reading mode for $5 \mathrm{~min}$. Data were collected and displayed in sequential $15 \mathrm{~s}$ bins. Data presented here are solely from viable cells that excluded the vital dye PI. The volume of spermatozoa was calculated from a standard curve obtained from the forward scatter of fluorescent spheres of known diameter (3, 4 and $5 \mu \mathrm{m}$ : Duke Scientific Corporation Palto Alto, CA, USA). A linear relationship between volume (fl: $y$ ) and forward scatter (mean channel number: $x$ ) was obtained $(y=0.211 x-41.336)$ with coefficients of correlation $(r)$ of 0.980 and determination $\left(r^{2}\right)$ of 0.961 . From this relationship, the mean ( \pm S.E.M.) volume of 160 control spermatozoa in hypotonic medium was $73 \pm 1 \mathrm{fl}$ and $82 \pm 1 \mathrm{fl}$ in the absence and presence of quinine respectively. In order to determine changes with time, absolute cell volumes were expressed as ratios of the first control samples ( $5 \mathrm{~min}$ in the long time-course protocol and $20 \mathrm{~s}$ in the initial time-course procotol).

\section{Inhibitors}

All reagents were the purest grade from Sigma. Quinine- $\mathrm{HCl}$, $\mathrm{HgCl}_{2}$ and $\mathrm{AgNO}_{3}$ were made up in water, whereas phoretin, cytochalasin B, phloridzin and furosemide were made up in DMSO. The final percentage of DMSO $(0.2 \% \mathrm{v} / \mathrm{v})$ had no effect on cell size (data not shown). Stock solutions of sodium azide (100 mM in water) and rotenone (20 mM in DMSO) were also prepared. In order to rule out the possibility that the metal ion effects were due to general toxicity, sperm volume and the response to quinine under hypotonic conditions were also measured when spermatozoa were pre-incubated (under initial time-course conditions) with the mitochondrial poisons at a final concentration of $20 \mu \mathrm{M}$.

\section{Statistical analysis}

Only the data from the long time-course experiments with phloridzin conformed to a normal distribution with equal variance and could be analysed by two-way ANOVA. No matter how transformed, the remaining data could not be made to meet the required assumptions; so the optimal statistical analysis (two-way ANOVA) could not be applied. One-way ANOVA on normally distributed data, otherwise KruskallWallis one-way ANOVA on ranks, was applied at relevant time points to illustrate the trends observed. When significant changes were found $(P<0.05)$, this was followed by all pairwise comparisons or against the relevant controls as appropriate (with Dunn's test for non-Gaussian distributions and the Holm-Sidak method for Gaussian) with the statistical program SigmaStat (Systat Software, Version 3.5, Erkrath, Germany).

\section{Declaration of interest}

The authors declare that there is no conflict of interest that could be perceived as prejudicing the impartiality of the research reported.

\section{Funding}

This work was supported by the DFG Grant YE37/8-1.

\section{References}

Agre P 2006 The aquaporin water channels. Proceedings of the American Thoracic Society 3 5-13.

Agre P \& Kozono D 2003 Aquaporin water channels: molecular mechanisms for human diseases. FEBS Letters 555 72-78.

Agre P, King LS, Yasui M, Guggino WB, Ottersen OP, Fujiyoshi Y, Engel A \& Nielsen S 2002 Aquaporin water channels - from atomic structure to clinical medicine. Journal of Physiology 542 3-16.

Aitken RJ, Fisher HM, Fulton N, Gomez E, Knox W, Lewis B \& Irvine S 1997 Reactive oxygen species generation by human spermatozoa is induced by exogenous NADPH and inhibited by the flavoprotein inhibitors diphenylene iodonium and quinacrine. Molecular Reproduction and Development 47 468-482.

Angulo C, Rauch MC, Droppelmann A, Reyes AM, Slebe JC, DelgadoLopez F, Guaiquil VH, Vera JC \& Concha II 1998 Hexose transporter expression and function in mammalian spermatozoa: cellular localization and transport of hexoses and vitamin C. Journal of Cellular Biochemistry 71 189-203.

Armstrong CM 2003 Voltage-gated K channels. Science's STKE 200310.

Augustin R, Carayannopoulos MO, Dowd LO, Phay JE, Moley JF \& Moley KH 2004 Identification and characterization of human glucose transporter-like protein-9 (GLUT9): alternative splicing alters trafficking. Journal of Biological Chemistry 279 16229-16236.

Barfield JP, Yeung CH \& Cooper TG 2005 The effects of putative $\mathrm{K}^{+}$channel blockers on volume regulation of murine spermatozoa. Biology of Reproduction 72 1275-1281.

Bienert GP, Moller AL, Kristiansen KA, Schulz A, Moller IM, Schjoerring JK \& Jahn TP 2007 Specific aquaporins facilitate the diffusion of hydrogen peroxide across membranes. Journal of Biological Chemistry 282 $1183-1192$.

Biggers JD, Whittem WK \& Whittingham DG 1971 The culture of mouse embryos in vitro. In Methods in Mammalian Embryology, pp 86-116. Ed. JC Daniel. San Francisco: Freeman.

Brooks HL, Regan JW \& Yool AJ 2000 Inhibition of aquaporin-1 water permeability by tetraethylammonium: involvement of the loop E pore region. Molecular Pharmacology 57 1021-1026.

Burant CF \& Davidson NO 1994 GLUT3 glucose transporter isoform in rat testis: localization, effect of diabetes mellitus, and comparison to human testis. American Journal of Physiology 267 R1488-R1495.

Burant CF, Takeda J, Brot-Laroche E, Bell GI \& Davidson NO 1992 Fructose transporter in human spermatozoa and small intestine is GLUT5. Journal of Biological Chemistry 267 14523-14526. 
Calamita G, Mazzone A, Cho YS, Valenti G \& Svelto M 2001 Expression and localization of the aquaporin-8 water channel in rat testis. Biology of Reproduction 64 1660-1666.

Castle NA 2005 Aquaporins as targets for drug discovery. Drug Discovery Today 10 485-493.

Coetzee WA, Amarillo Y, Chiu J, Chow A, Lau D, McCormack T, Moreno H, Nadal MS, Ozaita A, Pountney D et al. 1999 Molecular diversity of $\mathrm{K}^{+}$ channels. Annals of the New York Academy of Sciences 868 233-285.

Cooper TG \& Barfield JP 2006 Utility of infertile male models for contraception and conservation. Molecular and Cellular Endocrinology 250 206-211.

Cooper TG \& Yeung CH 2007 Involvement of potassium and chloride channels and other transporters in volume regulation by spermatozoa. Current Pharmaceutical Design 13 3222-3230.

Cooper TG, Barfield JP \& Yeung CH 2008 The tonicity of murine epididymal spermatozoa and their permeability towards common cryoprotectants and epididymal osmolytes. Reproduction 135 625-633.

Curry MR, Millar JD \& Watson PF 1995 The presence of water channel proteins in ram and human sperm membranes. Journal of Reproduction and Fertility 104 297-303.

Detmers FJ, de Groot BL, Muller EM, Hinton A, Konings IB, Sze M, Flitsch SL, Grubmuller H \& Deen PM 2006 Quaternary ammonium compounds as water channel blockers. Specificity, potency, and site of action. Journal of Biological Chemistry 281 14207-14214.

Doege H, Bocianski A, Joost HG \& Schurmann A 2000 Activity and genomic organization of human glucose transporter 9 (GLUT9), a novel member of the family of sugar-transport facilitators predominantly expressed in brain and leucocytes. Biochemical Journal 350 771-776.

Van Dop C, Hutson SM \& Lardy HA 1977 Pyruvate metabolism in bovine epididymal spermatozoa. Journal of Biological Chemistry 252 1303-1308.

Fischbarg J, Kuang KY, Hirsch J, Lecuona S, Rogozinski L, Silverstein SC \& Loike J 1989 Evidence that the glucose transporter serves as a water channel in 7774 macrophages. PNAS 86 8397-8401.

Fischbarg J, Kuang KY, Vera JC, Arant S, Silverstein SC, Loike J \& Rosen OM 1990 Glucose transporters serve as water channels. PNAS 87 3244-3247.

Gomez O, Romero A, Terrado J \& Mesonero JE 2006 Differential expression of glucose transporter GLUT8 during mouse spermatogenesis. Reproduction 131 63-70.

Gorelick DA, Praetorius J, Tsunenari T, Nielsen S \& Agre P 2006 Aquaporin-11: a channel protein lacking apparent transport function expressed in brain. BMC Biochemistry 714.

Haber RS, Weinstein SP, O'Boyle E \& Morgello S 1993 Tissue distribution of the human GLUT3 glucose transporter. Endocrinology 132 2538-2543.

Hasegawa H, Skach W, Baker O, Calayag MC, Lingappa V \& Verkman AS 1992 A multifunctional aqueous channel formed by CFTR. Science 258 1477-1479.

Helliwell PA, Richardson M, Affleck J \& Kellett GL 2000 Stimulation of fructose transport across the intestinal brush-border membrane by PMA is mediated by GLUT2 and dynamically regulated by protein kinase C. Biochemical Journal 350 149-154.

Ishibashi K 2006 Aquaporin superfamily with unusual npa boxes: $\mathrm{S}$-aquaporins (superfamily, sip-like and subcellular-aquaporins). Cellular and Molecular Biology 52 20-27.

Ishibashi K, Kuwahara M, Gu Y, Kageyama Y, Tohsaka A, Suzuki F, Marumo F \& Sasaki S 1997 Cloning and functional expression of a new water channel abundantly epressed in the testis permeable to water, glycerol, urea. Journal of Biological Chemistry 272 20782-20786.

Kasahara T \& Kasahara M 1997 Characterization of rat Glut4 glucose transporter expressed in the yeast Saccharomyces cerevisiae: comparison with Glut1 glucose transporter. Biochimica et Biophysica Acta 1324 111-119.

Kim ST \& Moley KH 2007 The expression of GLUT8, GLUT9a and GLUT9b in the mouse testis and sperm. Reproductive Sciences 14 445-455.

Klein T, Cooper TG \& Yeung CH 2006 The role of potassium chloride cotransporters in murine and human sperm volume regulation. Biology of Reproduction 75 853-858.

Kuwahara M, Gu Y, Ishibashi K, Marumo F \& Sasaki S 1997 Mercurysensitive residues and pore site in AQP3 water channel. Biochemistry 36 13973-13978.

Liu C, Gao D, Preston GM, McGann LE, Benson CT, Critser ES \& Critser JK 1995 High water permeability of human spermatozoa is mercuryresistant and not mediated by CHIP28. Biology of Reproduction $\mathbf{5 2}$ 913-919.
Loo DD, Zeuthen T, Chandy G \& Wright EM 1996 Cotransport of water by the $\mathrm{Na}^{+}$/glucose cotransporter. PNAS 93 13367-13370.

Loo DD, Hirayama BA, Meinild AK, Chandy G, Zeuthen T \& Wright EM 1999 Passive water and ion transport by cotransporters. Journal of Physiology 518 195-202.

Loo DD, Wright EM \& Zeuthen T 2002 Water pumps. Journal of Physiology 542 53-60.

Maher F, Davies-Hill TM \& Simpson IA 1996 Substrate specificity and kinetic parameters of GLUT3 in rat cerebellar granule neurons. Biochemical Journal 315 827-831.

Martin HJ, Kornmann F \& Fuhrmann GF 2003 The inhibitory effects of flavonoids and antiestrogens on the Glut1 glucose transporter in human erythrocytes. Chemico-Biological Interactions 146 225-235.

Meinild AK, Klaerke DA \& Zeuthen T 1998 Bidirectional water fluxes and specificity for small hydrophilic molecules in aquaporins $0-5$. Journal of Biological Chemistry 273 32446-32451.

Nielsen S, Kwon TH, Frokiaer J \& Agre P 2007 Regulation and dysregulation of aquaporins in water balance disorders. Journal of Internal Medicine 261 53-64.

Niemietz CM \& Tyerman SD 2002 New potent inhibitors of aquaporins: silver and gold compounds inhibit aquaporins of plant and human origin. FEBS Letters 531 443-447.

Nilius B 2004 Is the volume-regulated anion channel VRAC a 'waterpermeable' channel? Neurochemistry Research 29 3-8.

Pohl P 2004 Combined transport of water and ions through membrane channels. Biological Chemistry 385 921-926.

Preston GM, Jung JS, Guggino WB \& Agre P 1993 The mercury-sensitive residue at cysteine 189 in the CHIP28 water channel. Journal of Biological Chemistry 268 17-20.

Rigau T, Rivera M, Palomo MJ, Fernandez-Novell JM, Mogas T, Ballester J, Pena A, Otaegui PJ, Guinovart JJ \& Rodriguez-Gil JE 2002 Differential effects of glucose and fructose on hexose metabolism in dog spermatozoa. Reproduction 123 579-591.

Rosenfeld CR, Cornfield DN \& Roy T $2001 \mathrm{Ca}^{2+}$-activated K ${ }^{+}$channels modulate basal and E2-beta-induced rises in uterine blood flow in ovine pregnancy. American Journal of Physiology $281 \mathrm{H} 422-\mathrm{H} 431$.

Ruz R, Gregory M, Smith CE, Cyr DG, Lubahn DB, Hess RA \& Hermo L 2006 Expression of aquaporins in the efferent ductules, sperm counts, and sperm motility in estrogen receptor-alpha deficient mice fed lab chow versus casein. Molecular Reproduction and Development $\mathbf{7 3}$ 226-237.

Saito K, Kageyama Y, Okada Y, Kawakami S, Kihara K, Ishibashi K \& Sasaki S 2004 Localization of aquaporin-7 in human testis and ejaculated sperm: possible involvement in maintenance of sperm quality. Journal of Urology 172 2073-2076.

Sancho S, Casas I, Ekwall H, Saravia F, Rodriguez-Martinez H, RodriguezGil JE, Flores E, Pinart E, Briz M, Garcia-Cil N et al. 2007 Effects of cryopreservation on semen quality and the expression of sperm membrane hexose transporters in the spermatozoa of Iberian pigs. Reproduction 134 111-121.

Saparov SM \& Pohl P 2004 Beyond the diffusion limit: water flow through the empty bacterial potassium channel. PNAS 101 4805-4809.

Schurmann A, Axer H, Scheepers A, Doege H \& Joost HG 2002 The glucose transport facilitator GLUT8 is predominantly associated with the acrosomal region of mature spermatozoa. Cell and Tissue Research 307 237-242.

Da Silva N, Shum WW, El-Annan J, Paunescu TG, McKee M, Smith PJ, Brown D \& Breton S 2007 Relocalization of the V-ATPase B2 subunit to the apical membrane of epididymal clear cells of mice deficient in the B1 subunit. American Journal of Physiology. Cell Physiology 293 C199-C210.

Tsukaguchi H, Shayakul C, Berger UV, Mackenzie B, Devidas S, Guggino WB, van Hoek AN \& Hediger MA 1998 Molecular characterization of a broad selectivity neutral solute channel. Journal of Biological Chemistry 273 24737-24743.

Tsukaguchi H, Weremowicz S, Morton CC \& Hediger MA 1999 Functional and molecular characterization of the human neutral solute channel aquaporin-9. American Journal of Physiology 277 F685-F696.

Urner F \& Sakkas D 1999 A possible role for the pentose phosphate pathway of spermatozoa in gamete fusion in the mouse. Biology of Reproduction 60 733-739. 
Verkman AS 2005 More than just water channels: unexpected cellular roles of aquaporins. Journal of Cell Science 118 3225-3232.

Verkman AS \& Mitra AK 2000 Structure and function of aquaporin water channels. American Journal of Physiology. Renal Physiology 278 F13-F28.

Walker J, Jijon HB, Diaz H, Salehi P, Churchill T \& Madsen KL 2005 5-Aminoimidazole-4-carboxamide riboside (AICAR) enhances GLUT2dependent jejunal glucose transport: a possible role for AMPK. Biochemical Journal 385 485-491.

Yakata K, Hiroaki Y, Ishibashi K, Sohara E, Sasaki S, Mitsuoka K \& Fujiyoshi Y 2007 Aquaporin-11 containing a divergent NPA motif has normal water channel activity. Biochimica et Biophysica Acta $\mathbf{1 7 6 8}$ 688-693.

Yang B \& Verkman AS 1998 Urea transporter UT3 functions as an efficient water channel. Direct evidence for a common water/urea pathway. Journal of Biological Chemistry 273 9369-9372.

Yang B \& Verkman AS 2002 Analysis of double knockout mice lacking aquaporin-1 and urea transporter UT-B. Evidence for UT-B-facilitated water transport in erythrocytes. Journal of Biological Chemistry 277 36782-36786.

Yang B, Kim JK \& Verkman AS 2006 Comparative efficacy of $\mathrm{HgCl}_{2}$ with candidate aquaporin-1 inhibitors DMSO, gold, $\mathrm{TEA}^{+}$and acetazolamide. FEBS Letters $\mathbf{5 8 0}$ 6679-6684.
Yeung CH, Sonnenberg-Riethmacher E \& Cooper TG 1999 Infertile spermatozoa of c-ros tyrosine kinase receptor knockout mice show flagellar angulation and maturational defects in cell volume regulatory mechanisms. Biology of Reproduction 61 1062-1069.

Yeung CH, Wagenfeld A, Nieschlag E \& Cooper TG 2000 The cause of infertility of male c-ros tyrosine kinase receptor knockout mice. Biology of Reproduction 63 612-618.

Yeung CH, Barfield JP \& Cooper TG 2005 The role of anion channels and $\mathrm{Ca}^{2+}$ in addition to $\mathrm{K}^{+}$channels in the physiological volume regulation of murine spermatozoa. Molecular Reproduction and Development $\mathbf{7 1}$ 368-379.

Yeung CH, Barfield JP \& Cooper TG 2006 Physiological volume regulation by spermatozoa. Molecular and Cellular Endocrinology 250 98-105.

Zeuthen T, Meinild AK, Loo DD, Wright EM \& Klaerke DA 2001 Isotonic transport by the $\mathrm{Na}^{+}$-glucose cotransporter SGLT1 from humans and rabbit. Journal of Physiology 531 631-644.

Received 28 January 2008

First decision 19 March 2008

Revised manuscript received 30 June 2008

Accepted 9 July 2008 